\title{
Students' Perceptions of Life Skill Development in Project-Based Learning Schools
}

\author{
Kimberly Meyer (Corresponding author) \\ Department of Educational Leadership, Minnesota State University \\ 115 Armstrong Hall, Mankato, MN 56001, USA
}

Tel: 1-507-933-7455_E-mail: kmeyer7@gustavus.edu

\begin{abstract}
Scott Wurdinger
Department of Educational Leadership, Minnesota State University

115 Armstrong Hall, Mankato, MN 56001, USA

Tel: 1-507-389-2919Ｅ-mail: scott.wurdinger@mnsu.edu
\end{abstract}

Received: January 23, 2016 Accepted: February 18, 2016 Published: February 19, 2016

doi:10.5296/jei.v2i1.8933 URL: http://dx.doi.org/10.5296/jei.v2i1.8933

\begin{abstract}
This research aimed to examine students' perceptions of their life skills while attending project-based learning (PBL) schools. The study focused on three questions including: 1) What are students' perceptions of their development of life skills in project-based learning schools? 2) In what ways, if any, do students perceive an increase in their life skill development over a one-year period of time? 3) What relationship, if any, is there between grade level and students' perceptions of their life skills? The subjects were 275 6-12 students from two project-based learning charter schools in Minnesota. One school was located in a rural location; the other in an urban location. The triangulating data collection methods included a Likert-scale survey, semi-structured interviews, and focus groups. Quantitative analysis using SPSS were used to analyze the survey data. Qualitative analysis methods used were coding and identification of emergent themes. Qualitative results showed perceptions of most improved skills as time management, collaboration, communication, and self-directedness. Quantitative data results showed most improved skills within an academic year as responsibility, problem-solving, self-directedness, and work ethic. Self-directedness was the single skill that was evident in all data results. The results showed students' perceptions of their life skills were positive and that project-based learning helped them
\end{abstract}


develop multiple life skills including, but not limited to communication, collaboration, problem-solving, responsibility, and time management. Implications of this research suggest that project-based learning has a positive influence on students' life skills development across 6-12 grade levels and helps prepare them to be successful in the $21^{\text {st }}$ century global community and economy.

Keywords: Charter schools, Constructivism, Constructionism, Project-based learning, Life skills, Self-efficacy, EdVisions, The No Child Left Behind Act (NCLB)

\section{Introduction}

In an educational era where student achievement and skills are based primarily on standardized assessments, performance-based options are limited due to federal mandates. President Obama, during his first months in office, called for the development of standards and assessments that measure more than memorization of information. He stated that we need to find out whether students possess skills for the $21^{\text {st }}$ century, skills such as problem solving, critical thinking, creativity, and entrepreneurship (Toch, 2011).

There is a problem with basing student achievement and skills solely on quantitative standardized assessments that by their very nature are limited in their ability to measure beyond rote memorization and basic skills. Performance-based assessments, however, may provide a more holistic picture of students' understandings and abilities; this would allow educators to measure the $21^{\text {st }}$ century skills that President Obama spoke of: critical thinking, synthesizing, problem solving, and creativity (Toch, 2011).

Qualitative inquiry is described by Creswell (1998), co-director of the Office of Qualitative and Mixed Methods Research at the University of Nebraska-Lincoln, as multifaceted and one that requires us to reflect on issues by studying various components. Standardized assessments cannot measure those multiple dimensions and the complexity of learning. Quantitative measures of student learning offer only one dimension of their knowledge. According to Tashlik (2010), performance assessments are qualitative measures that can produce more comprehensive data, which leads to a better understanding of students' abilities and needs.

Formative assessments, in general, are those that provide information about student learning during instruction; with formative assessment, careful planning and deliberation is required to ensure credibility. According to Popham (2008), the criteria for planning formative assessments must include determining what should be measured, how it should be measured, and what adjustments will be made to instruction as teachers continually link assessment to instructional objectives. Formative assessments should be authentic and multidimensional as student performance data is collected in order to know how to tailor instruction that will promote students' abilities and higher level thinking (Peverini, 2009).

Research in the past decade has pointed to a number of benefits with using formative assessment, in particular, the project-based learning approach. Project-based learning is a constructivist-based instructional approach that uses "projects" to engage learning, encourage student motivation, and provide a method for explaining and demonstrating understanding 
(Barron \& Darling-Hammond, 2008; Savery, 2006). According to Trilling and Hood (1999) and Wurdinger and Qureshi (2015) project-based learning also promotes not only academic rigor, but life skills such as communication, critical thinking, and collaboration. Charter schools tend to implement project-based learning more than mainstream public schools because of their freedom in designing curriculum (Wurdinger, Haar, Hugg, \& Bezon, 2007). Problem solving is a vital element in project-based learning and stems from a constructivist concept.

Because no two teachers teach project-based learning in the same way, defining and measuring its effectiveness is somewhat difficult. Ravitz (2009) operationally defined project-based learning using a broad approach to instruction as (a) an in-depth inquiry, (b) happening over an extended time, (c) student self-directed to some extent, and (d) requiring a formal presentation of results. Other features that contributed to the effectiveness of project-based learning included scaffolds and technology supports, meaningful group work, integration of multiple subject areas, intentional use of direct instruction, a connection to the local community, and ongoing assessments (Ravitz, 2009).

In a number of studies that have focused on project-based learning, it was found to be as effective as traditional approaches (Strobel \& van Barneveld, 2008; Walker \& Leary, 2008). Specifically, project-based learning has been shown to enable students to learn how to work in groups, communicate what they have learned, and solve problems. It increases understanding of concepts while increasing the ability to apply knowledge as measured by standardized tests (Geier et al., 2008). Project-based learning has been effective in improving attitudes and motivation (Boaler, 1997) and has been especially strategic with lower achieving students (Geier et al., 2008; Hickey et al., 1999; Lynch, Kuipers, Pyke, \& Szesze, 2005).

Some research suggests that project-based learning develops students' higher-level thinking in areas such as problem-solving skills, planning, and self-monitoring (Brown \& Campione, 1996). Students become proficient in transferring conceptual ideas throughout various learning situations (Brown \& Campione, 1996; Scardamalia \& Bereiter, 1991). According to Katz (1989), there are positive effects to students' self-esteem and dispositions. Although project-based learning provides enriched authentic learning opportunities and allows students to investigate and apply real-world problems and situations (Mitchell et al., 2009), the traditional teacher-directed pedagogical beliefs are deeply embedded within the public school systems and culture.

Project-based learning requires in-depth learning about issues and themes that are directly related to standards in the various content areas. Students develop ownership because they choose personally relevant projects and learn to self-monitor as they identify goals, resources, and timelines that enable them to accomplish their tasks. Teachers take on the roles of advisors, facilitators, and coaches. Although they do not resign their control of the learning, the students take part in the learning situations and teachers are able to better facilitate and differentiate learning for each individual student. Collaboration is a key component. Students learn collaboration skills as they share ideas and points of view with their instructors, peers, 
and adults within the community. They continually reflect on their work through portfolios, journals, and evaluation rubrics that are designed to help them reach their personal goals. According to the Buck Institute for Education (2002), project-based learning helps students master both content and process. It emphasizes real-world skills, integrates various disciplines, and meets the needs of a wide range of learning styles. It actively engages students as they delve into more profound levels of learning (Harada, Kirio, \& Yamamoto, 2008). Newell (2003) defines project-based learning as emphasizing student interest rather than following a fixed curriculum. It has a broad interdisciplinary application that focuses on data and materials developed by students rather than teachers.

With project-based learning, assessment is authentic. It measures skills that are not measurable through standardized tests. A student's mastery of skills is measured through performance-based assessment including rubrics, self-evaluation, and reflection (Bell, 2010). Through collaboration, solving real-world problems, and inquiry through deep learning and research, students are able to develop critical skills that will help prepare them for $21^{\text {st }}$ century needs.

\section{Purpose}

The purpose of this research was to examine 6-12 grade students' perceptions of their life skill development at two project-based learning charter schools over a one-year period (2012-2013). The research subjects were students at Avalon Charter School in St Paul, Minnesota with an enrollment of 190, and Minnesota New Country School (MNCS) in Henderson, Minnesota with an enrollment of 113. Specific life skills not determined in advance may surface and will be included in the results. Previous sentence is unclear ... maybe delete it? Project-based learning was identified in this study as curriculum that is driven through inquiry, student choice, and individualized learning plans.

\section{Research Questions}

1) What are students' perceptions of their development of life skills in project-based learning schools?

2)In what ways, if any, do students perceive an increase in their life skill development over a one-year period of time?

3) What relationship, if any, is there between grade level and students' perceptions of their life skills?

\section{Research Methods}

Primary quantitative and qualitative data was collected and analyzed through student interviews, surveys, and focus groups from a sample of sixth through twelfth grade students. The goal of this research was to provide further data that may lead to a better understanding of how to increase student life skills through project-based learning.

The sample size of the analytical survey data included 275 sixth through twelfth grade students at the two schools. I would delete this reference. The sample size of the qualitative 
interviews included a random selection of 26 sixth through twelfth grade students from the two schools. Although 15 students was the intended number of students requested from both Avalon and MNCS, only 12 students from Avalon and 14 students from MNCS chose to participate in the interviews (see Appendix 1). The intended number of students requested from both Avalon and MNCS for focus groups was six. Six students from Avalon and five students from MNCS chose to participate in the focus group (see Appendix 2).

\section{Results}

A total of 275 6-12 $2^{\text {th }}$ grade students from the two schools completed a thirty-seven question Likert-type survey during the 2012-2013 school year (see Appendix 3).

The first question of the survey asked students how long they had been at the school. The second question asked students their current grade level. The remaining thirty-four questions asked students to rank themselves on eight different life skills, which were then used to compute scores of central tendency and spread on these eight dimensions. Each of the eight life skills had several corresponding questions, which is found directly below.

> Time Management: 3, 16, 21, 32

> Responsibility: 9, 13, 22, 28

$>$ Problem Solving: 4, 6, 17, 23, 33

$>$ Self-Directedness: 5, 18, 25, 30

$>$ Collaboration: $7,8,10,15$

$>$ Communication: 12, 20, 24, 27, 34

$>$ Creativity: 14, 19, 26

$>$ Work Ethic: 11, 29, 31, 35

$>$ Overall Improvement: 36

Scale Used: 1 = Poor; 2 = Fair; 3 = Satisfactory; 4 = Good; 5 = Excellent

Question 37 was an open-ended question that asked students what life skills they thought were important to best prepare them for college, and will be discussed at the end of the quantitative section.

Several $t$ tests were conducted in order to compare responses between fall and spring semesters. Dependent samples $t$ tests were not possible due to the fact that cases were not matched across semesters. Independent samples $t$ tests were conducted instead (which introduces greater error into the analysis as a control for individual unmatched differences).

Eight $t$ tests were conducted, one for each of the life skills and, in order to correct for family-wise error resulting from multiple tests, a Bonferroni correction was applied. This means that the standard of level of significance (.05, meaning a 1 in 20 chance of a false positive result) was adjusted, in this case with the formula of $05(.95) n-1$, where $n=$ the 
number of tests performed. After this correction, a $p$ value (significance level) of $<.035$ was required for a $t$ test to be significant.

Fall and Spring scores from all 275 student survey responses were combined to examine the average overall perceptions for each dimension (see Table 1). Overall scores from all 275 student survey responses were also examined to compare Fall and Spring responses (see Table 2).

Table 1. Combined fall and spring average for each dimension

\begin{tabular}{|c|c|c|c|c|c|c|c|c|c|}
\hline & $\underset{\tilde{\Xi}}{\stackrel{\omega}{0}}$ & 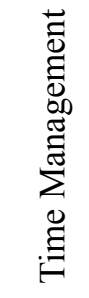 & 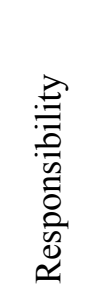 & 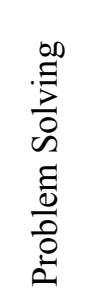 & 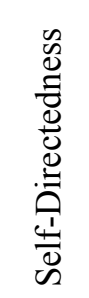 & 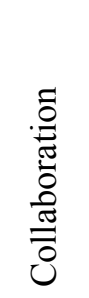 & 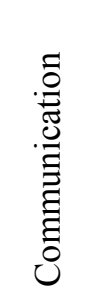 & 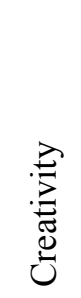 & 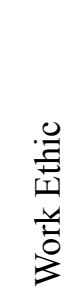 \\
\hline $\mathrm{N}$ & 274 & 275 & 274 & 275 & 274 & 274 & 274 & 274 & 274 \\
\hline Mean & 2.21 & 3.37 & 3.67 & 3.75 & 3.52 & 3.60 & 3.81 & 3.92 & 3.45 \\
\hline Std. Deviation & 1.35 & 0.85 & 0.83 & 0.72 & 0.81 & 0.79 & 0.72 & 0.69 & 0.82 \\
\hline Median & 2.00 & 3.25 & 3.67 & 3.80 & 3.50 & 3.75 & 3.83 & 4.00 & 3.50 \\
\hline Minimum & 1.00 & 1.25 & 1.67 & 1.00 & 1.00 & 1.00 & 1.00 & 2.00 & 1.00 \\
\hline Maximum & 5.00 & 5.00 & 5.00 & 5.00 & 5.00 & 5.00 & 5.00 & 5.00 & 5.00 \\
\hline Range & 4.00 & 3.75 & 3.33 & 4.00 & 4.00 & 4.00 & 4.00 & 3.00 & 4.00 \\
\hline
\end{tabular}

Table 2.Overall group statistics comparing fall and spring

\begin{tabular}{|c|l|l|l|}
\hline & Mean & Std. Deviation & Std. Error Mean \\
\hline Time Management & & & \\
\hline Fall 2012 $^{\mathrm{a}}$ & 3.392 & 0.805 & 0.063 \\
\hline Spring 2013 $^{\mathrm{b}}$ & 3.344 & 0.919 & 0.086 \\
\hline Responsibility & & & \\
\hline Fall 2012 $^{\mathrm{a}}$ & 3.668 & 0.802 & 0.063 \\
\hline Spring 2013 & 3.676 & 0.867 & 0.082 \\
\hline Problem Solving & & & \\
\hline Fall 2012 & & 0.696 & 0.055 \\
\hline Spring 2013 & 3.742 & 0.764 & 0.072 \\
\hline Self Directedness & 3.769 & & \\
\hline
\end{tabular}




\begin{tabular}{|c|c|c|c|}
\hline Fall $2012^{\mathrm{a}}$ & 3.512 & 0.781 & 0.061 \\
\hline Spring $2013^{c}$ & 3.525 & 0.852 & 0.081 \\
\hline \multicolumn{4}{|l|}{ Collaboration } \\
\hline Fall $2012^{\mathrm{a}}$ & 3.617 & 0.747 & 0.059 \\
\hline Spring $2013^{c}$ & 3.805 & 0.860 & 0.081 \\
\hline \multicolumn{4}{|l|}{ Communication } \\
\hline Fall $2012^{\mathrm{a}}$ & 3.811 & 0.710 & 0.056 \\
\hline Spring $2013^{\mathrm{c}}$ & 3.805 & 0.744 & 0.056 \\
\hline \multicolumn{4}{|l|}{ Creativity } \\
\hline Fall $2012^{\mathrm{a}}$ & 3.943 & 0.686 & 0.054 \\
\hline Spring $2013^{c}$ & 3.884 & 0.694 & 0.066 \\
\hline \multicolumn{4}{|l|}{ Work Ethic } \\
\hline Fall $2012^{\mathrm{a}}$ & 3.432 & 0.804 & 0.063 \\
\hline Spring $2013^{\mathrm{c}}$ & 3.481 & 0.848 & 0.080 \\
\hline
\end{tabular}

Note. ${ }^{a} \mathrm{n}=162 ;{ }^{\mathrm{b}}=113$.

The Levene's Test for Equality was used to adjust for inequality among groups. No $t$ tests revealed significant differences between the two semesters. Combined Fall and Spring averages for each dimension were split by grade groups (middle school student, HS underclassmen, and HS upperclassmen) to examine possible differences between grade groups (see Table 3).

Table 3. Combined fall and spring for each dimension by grade groups

\begin{tabular}{|l|l|l|l|l|}
\hline & N & Mean & Std. Deviation & Std. Error \\
\hline Time Management & & & & \\
\hline Middle School Student (6-8) & 64 & 3.51 & 0.90 & 0.11 \\
\hline HS Underclassman (9-10) & 91 & 3.23 & 0.77 & 0.08 \\
\hline HS Upperclassman (11-12) & 118 & 3.40 & 0.88 & 0.08 \\
\hline Total & 273 & 3.37 & 0.85 & 0.05 \\
\hline Responsibility & & & & \\
\hline Middle School Student (6-8) & 63 & 3.59 & 0.97 & 0.12 \\
\hline HS Underclassman (9-10) & 91 & 3.49 & 0.71 & 0.07 \\
\hline HS Upperclassman (11-12) & 118 & 3.85 & 0.81 & 0.07 \\
\hline
\end{tabular}




\begin{tabular}{|c|c|c|c|c|}
\hline Total & 272 & 3.67 & 0.83 & 0.05 \\
\hline \multicolumn{5}{|l|}{ Problem Solving } \\
\hline Middle School Student (6-8) & 64 & 3.68 & 0.79 & 0.10 \\
\hline HS Underclassman (9-10) & 91 & 3.68 & 0.67 & 0.07 \\
\hline HS Upperclassman (11-12) & 118 & 3.85 & 0.73 & 0.07 \\
\hline Total & 273 & 3.75 & 0.73 & 0.04 \\
\hline \multicolumn{5}{|l|}{ Self Directedness } \\
\hline Middle School Student (6-8) & 63 & 3.39 & 0.96 & 0.12 \\
\hline HS Underclassman (9-10) & 91 & 3.48 & 0.67 & 0.07 \\
\hline HS Upperclassman (11-12) & 118 & 3.60 & 0.82 & 0.08 \\
\hline Total & 272 & 3.51 & 0.81 & 0.05 \\
\hline \multicolumn{5}{|l|}{ Collaboration } \\
\hline Middle School Student (6-8) & 63 & 3.56 & 0.91 & 0.12 \\
\hline HS Underclassman (9-10) & 91 & 3.56 & 0.61 & 0.06 \\
\hline HS Upperclassman (11-12) & 118 & 3.64 & 0.86 & 0.08 \\
\hline Total & 272 & 3.60 & 0.80 & 0.05 \\
\hline \multicolumn{5}{|l|}{ Communication } \\
\hline Middle School Student (6-8) & 63 & 3.70 & 0.88 & 0.11 \\
\hline HS Underclassman (9-10) & 91 & 3.73 & 0.60 & 0.06 \\
\hline HS Upperclassman (11-12) & 118 & 3.93 & 0.71 & 0.06 \\
\hline Total & 272 & 3.81 & 0.72 & 0.04 \\
\hline \multicolumn{5}{|l|}{ Creativity } \\
\hline Middle School Student (6-8) & 63 & 3.93 & 0.66 & 0.08 \\
\hline HS Underclassman (9-10) & 91 & 3.86 & 0.58 & 0.06 \\
\hline HS Upperclassman (11-12) & 118 & 3.95 & 0.78 & 0.07 \\
\hline Total & 272 & 3.91 & 0.69 & 0.04 \\
\hline \multicolumn{5}{|l|}{ Work Ethic } \\
\hline Middle School Student (6-8) & 63 & 3.46 & 0.87 & 0.11 \\
\hline HS Underclassman (9-10) & 91 & 3.35 & 0.70 & 0.07 \\
\hline HS Upperclassman (11-12) & 118 & 3.53 & 0.88 & 0.08 \\
\hline Total & 272 & 3.45 & 0.82 & 0.05 \\
\hline
\end{tabular}

Note. $\mathrm{CI}=$ confidence interval. 
One-way analysis of variance (ANOVA) was used to identify differences on a continuous dependent variable between groups of a categorical independent variable. A significant $F$ ratio (where the $p$ value in the sig. column is less than .05) indicates that a statistically significant difference exists between the groups. Since multiple ANOVAs were conducted, the $p$ value required for statistical significance was adjusted to .033 in order to correct for family-wise error using a Bonferroni correction (the increase of finding a false significant result due to chance when multiple tests are performed; in this case, correcting for a total of 9 ANOVAs (see Table 4).

Table 4. ANOVA

\begin{tabular}{|c|c|c|c|c|c|}
\hline & Sum of Squares & df & Mean Square & $\mathrm{F}$ & Sig. \\
\hline \multicolumn{6}{|l|}{ Time Management } \\
\hline Between Groups & 3.117 & 2 & 1.559 & 2.153 & 0.118 \\
\hline Within Groups & 195.415 & 270 & 0.724 & & \\
\hline Total & 198.532 & 272 & & & \\
\hline \multicolumn{6}{|l|}{ Responsibility } \\
\hline Between Groups & 7.008 & 2 & 3.504 & 5.270 & 0.006 \\
\hline Within Groups & 178.853 & 269 & 0.665 & & \\
\hline Total & 185.860 & 271 & & & \\
\hline \multicolumn{6}{|l|}{ Problem Solving } \\
\hline Between Groups & 1.899 & 2 & 0.949 & 1.813 & 0.165 \\
\hline Within Groups & 141.344 & 270 & 0.523 & & \\
\hline Total & 143.242 & 272 & & & \\
\hline \multicolumn{6}{|l|}{ Self Directedness } \\
\hline Between Groups & 2.002 & 2 & 1.001 & 1.532 & 0.218 \\
\hline Within Groups & 175.841 & 269 & 0.654 & & \\
\hline Total & 177.844 & 271 & & & \\
\hline \multicolumn{6}{|l|}{ Collaboration } \\
\hline Between Groups & 0.421 & 2 & 0.211 & 0.330 & 0.719 \\
\hline Within Groups & 171.524 & 269 & 0.638 & & \\
\hline Total & 171.945 & 271 & & & \\
\hline \multicolumn{6}{|l|}{ Communication } \\
\hline Between Groups & 2.917 & 2 & 1.458 & 2.825 & 0.061 \\
\hline Within Groups & 138.883 & 269 & 0.516 & & \\
\hline Total & 141.800 & 271 & & & \\
\hline
\end{tabular}




\begin{tabular}{|l|l|l|l|l|l|}
\hline Creativity Dimension & & & & & \\
\hline Between Groups & 0.474 & 2 & 0.237 & 0.497 & 0.609 \\
\hline Within Groups & 128.289 & 269 & 0.477 & & \\
\hline Total & 128.763 & 271 & & & \\
\hline Work Ethic & & & & & \\
\hline Between Groups & 1.726 & 2 & 0.863 & 1.276 & 0.281 \\
\hline Within Groups & 181.918 & 269 & 0.676 & & \\
\hline Total & 183.644 & 271 & & & \\
\hline
\end{tabular}

Since there were more than two groups, post-hoc tests were used to determine if there was a significant $F$-ratio and where the difference or differences existed. $F$ ratios found in the ANOVA table were adjusted in order to compensate for the violation of the test's assumption of homogeneity of variances. This adjustment was performed by conducting Welch and Brown-Forsythe "Robust Tests of Equality of Means", which provide adjusted $F$ ratios that are more appropriate for interpretation. The Welch Robust Test of Equality showed (Sig. $=.003$ ) for responsibility.

Following $F$ ratio adjustments, the Games-Howell post-hoc test was conducted and chosen due to the inequality of variance among the groups and because the samples sizes of the groups were unequal. This test showed that high school underclassmen's scores on responsibility were significantly different (lower) than high school upperclassmen's scores: $-0.355(p=.002)$. There were no other significant pairs of scores (see Table 5).

Table 5. Multiple comparisons

\begin{tabular}{|c|c|c|c|c|c|c|}
\hline (I) Grade Group & (J) Grade Group & $\begin{array}{l}\text { Mean } \\
\text { Difference } \\
(\mathrm{I}-\mathrm{J})\end{array}$ & $\begin{array}{l}\text { Std. } \\
\text { Error }\end{array}$ & Sig. & $\begin{array}{l}95 \% \\
\text { Confidence } \\
\text { Level Lower }\end{array}$ & $\begin{array}{l}95 \% \\
\text { Confidence } \\
\text { Level Upper }\end{array}$ \\
\hline \multirow{2}{*}{$\begin{array}{l}\text { Middle School } \\
\text { Student }\end{array}$} & $\begin{array}{l}\text { HS } \\
\text { Underclassmen }\end{array}$ & 0.095 & 0.142 & 0.785 & -0.244 & 0.433 \\
\hline & $\begin{array}{l}\text { HS } \\
\text { Upperclassmen }\end{array}$ & -0.260 & 0.142 & 0.166 & -0.599 & 0.078 \\
\hline \multirow{2}{*}{$\begin{array}{l}\text { HS } \\
\text { Underclassmen }\end{array}$} & $\begin{array}{l}\text { Middle School } \\
\text { Student }\end{array}$ & -0.095 & 0.142 & 0.785 & -0.433 & 0.244 \\
\hline & $\begin{array}{l}\text { HS } \\
\text { Upperclassmen }\end{array}$ & $-0.355^{*}$ & 0.105 & 0.002 & -0.603 & -0.107 \\
\hline \multirow{2}{*}{$\begin{array}{l}\text { HS } \\
\text { Upperclassmen }\end{array}$} & $\begin{array}{l}\text { Middle School } \\
\text { Student }\end{array}$ & 0.260 & 0.142 & 0.166 & -0.078 & 0.599 \\
\hline & $\begin{array}{l}\text { HS } \\
\text { Underclassman }\end{array}$ & $.355^{*}$ & 0.105 & 0.002 & 0.107 & 0.603 \\
\hline
\end{tabular}

Note. Dependent Variable $=$ Responsibility. Games-Howell. *Significant at the 0.05 level. 
The bar graph of responsibility provided information showing the difference in mean responsibility scores between the different grade groups. High school upperclassmen were significantly higher in their responsibility score than high school underclassmen. Although they also scored higher in responsibility than middle school, the difference was not significant (see Figure 1).

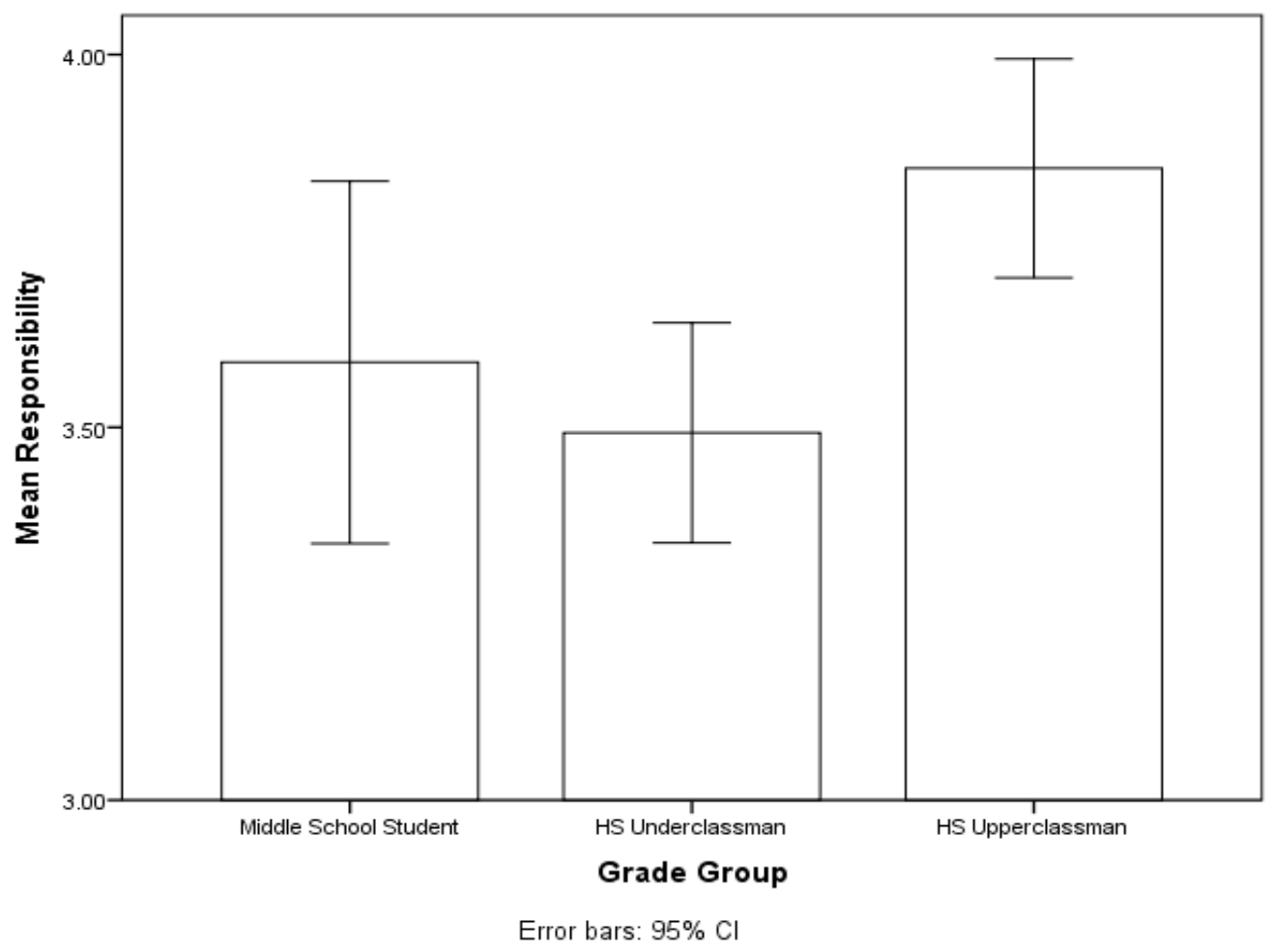

Figure 1. Graph of responsibility scores

The average of years that each student group was at the project-based learning school was also examined. The total average time that all students had been at their particular school was 2.21 years. There were no significant correlations between years at the school and mean scores on survey item dimensions.

The Likert scale survey question 36 was not used in the previous data because it did not fall into any of the eight categories. Question 36 asked how students perceived improvement of their life skills. Students ranked their overall improvement of life skills as good (50.18\%).

The last section of the survey was composed of one open-ended question providing for a written response. Question 37 asked students which life skills they thought were important to best prepare for college. Only 225 out of 275 students responded to this question (see Figure 2). 


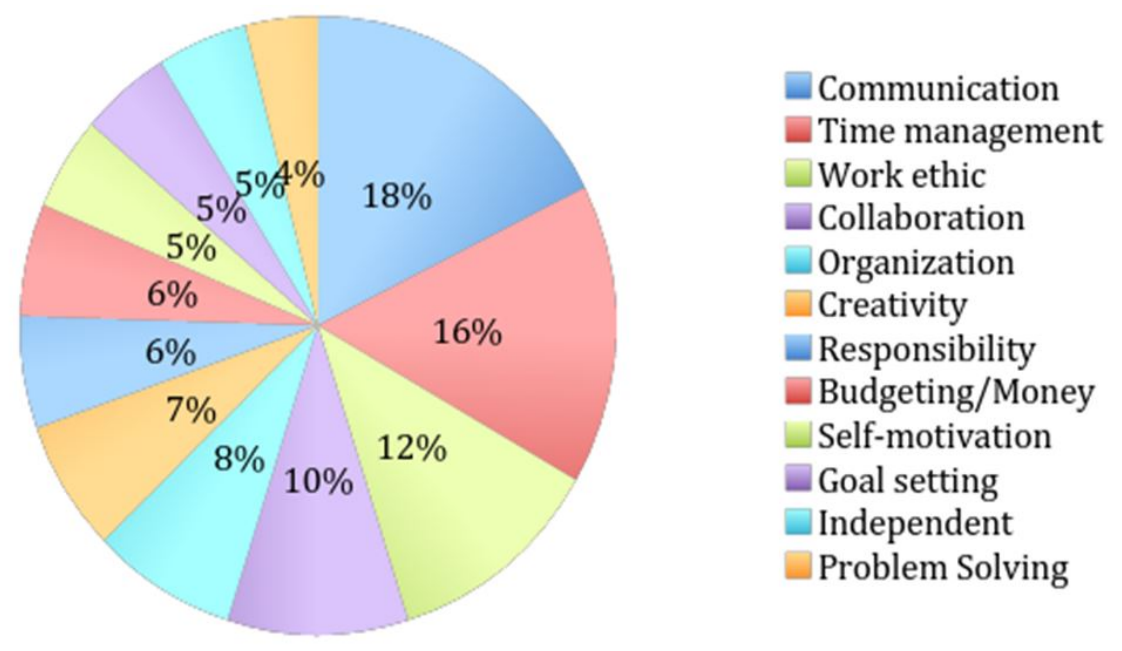

Figure 2. Life skills needed to best prepare for college by Avalon and MNCS students Note. $\mathrm{n}=225$ students who responded to survey question 37 .

\section{Qualitative Findings}

\subsection{Avalon}

A significant focus of this research was to better understand what students perceived as important life skills. A total of eighteen students from Avalon grades 7-12 were interviewed, combining individual and focus group sessions. The two perceptions that were higher were communication $(72 \%)$ and time management $(61 \%)$. Although the other categories were lower, they should still be given consideration due to the students' perceptions that those categories were important.

Students' perceptions of their most improved life skills while attending Avalon were examined through interviews and the focus group. A significant result of $38.89 \%$ perceived communication as their most improved life skill, and $33.33 \%$ perceived time management and self-directedness/independence as their most improved life skills

The individual interviews and focus group students were asked if they had any suggestions for improvement at Avalon. The most common response was satisfied with no recommendations. Suggestions that were made by more than one student included improved communication among students and teachers; allow for more creativity, and help students be more responsible.

\subsection{MNCS}

MNCSstudents' perceptions of important life skills were also examined. Self-directedness/independence was perceived to be most important, followed by communication/social skills, time management and collaboration.

Communication, collaboration, and self-directedness/independence were perceived by students at MNCS to be the life skills that they had most improved on while attending MNCS. 
Communication was the highest, followed by collaboration, and self-directedness/independence.

The individual interviews and focus group students were asked if they had any suggestions for improvement at MNCS. The most common responses included needing more direction and assistance with projects, allowing more creativity, increased math education, and a more rigid structure.

\section{Discussion}

The first question of this research study examined students' perceptions of their life skill development in project-based learning schools. The data collected from this research study shows that students from both schools perceive life skills as important and perceive their life skill development in a variety of ways. Students are learning important life skills and perceive an increase in life skills while attending their project-based learning schools.

The quantitative data from the survey shows that there is a strong correlation among students' perceptions of important life skills at both schools. Avalon students perceive communication, time management, self-directedness, and collaboration as the four most important life skills. Similarly, MNCS students perceive self-directedness, communication, and time management as the three most important life skills.

When both focus groups at Avalon and MNCS were asked about what particular life skills were important, common themes that occurred included time management, communication, creativity, self-directedness/independence, goal setting and collaboration.

The second question of this research study examined students' perceptions of improved life skills over a one-year period of time. Fall and spring scores from all 275 student survey responses were combined to examine the average overall perceptions for each dimension. There was an increase in four of the dimensions from fall to spring. Those skills that increased were responsibility, problem solving, self-directedness, and work ethic. The work ethic dimension increased the most from 3.43 in the fall, to 3.48 in the spring. Four dimensions decreased from fall to spring. Those skills included time management, collaboration, communication, and creativity. Creativity was shown to decrease the most from 3.94 in the fall to 3.88 in the spring. This data should be viewed cautiously to not make a general assumption that all students increased or decreased over a one-year period of time. The Levene's Test for Equality, an independent samples test, was used to adjust for inequality among groups and time management was significant at .031, t-tests found no significant differences between the two semesters. It would be valuable to compare each group to themselves from fall to spring and individual grade level perceptions from fall to spring on each of the eight dimensions, but the inequality of groups and grade levels made it difficult. This data would be more indicative of specific increases and/or decreases in perceptions.

Question 36 in the survey asked students to rank their perception of overall improvement of life skills. Evidence that $50.18 \%$ of students from both schools perceived improvement in their life skills as good, and $27.473 \%$ of students perceived their improvement in their life skills as excellent. Only $1.465 \%$ of students perceived their improvement of life skills as poor. 
This provides insights into how satisfied students feel about their life skills while attending these schools. Although there are students who perceive the improvement of the life skills as poor while attending one of these schools, the majority of students perceived a positive improvement of their life skills.

This study also looked at grade level mean scores and compared students Question 36 scores from fall to spring using the Likert scale survey. Only one sixth grade student answered the question, so this score was not included in the results. Likert scale ranking was 1 (poor), 2 (fair), 3 (satisfactory), 4 (good), and 5 (excellent). Seventh grade students' scores went down from 4.33 (good) in the fall to 3.47 (satisfactory) in the spring. Eighth grade students went up from 3.88 (satisfactory) in the fall to 4.2 (good) in the spring. Ninth grade students went down from 4.05 (good) in the fall to 3.69 (satisfactory) in the spring. Tenth grade students went down from 4.09 (good) in the fall to 3.9 (satisfactory) in the spring. Eleventh grade students went up from 3.96 (satisfactory) in the fall to 4.28 (good) in the spring. Twelfth grade students went down from 4.29 (good) in the fall to 3.85 (satisfactory) in the spring. The change in perceptions from fall to spring could be due to many factors including workload, stress, classroom environment, home life, expectations, graduation requirements, etc. Interestingly, only the eighth grade and eleventh grade students' perceptions increased from fall to spring. Reasons for this increase for eighth and eleventh grade students may be due to how they perceive the importance of those life skills and their academic progress during that school year. However, overall perceptions from each grade group were either good or satisfactory.

During interviews and focus groups, common themes of life skills students' perceived as having improved on the most during their time at Avalon and MNCS emerged. Communication was ranked highest, followed by self-directedness/independence, then collaboration. These three life skills were ranked high in both categories of important life skills, and life skills that students felt they had improved upon. Those same life skills that students perceived as important were also shown to be skills they felt they had improved on while attending Avalon and MNCS.

Interestingly, students from both project-based learning schools stated that project-based learning facilitates personal growth, because students design everything on their own which helps them learn from their own failures. They stated that they have learned to work better with others as well as become more self-aware and independent. Their motivation and organization improved while attending Avalon and MNCS because they have to set their own deadlines in order to complete their work and succeed.

The third question of this research examined the possible relationship between grade level and students' perceptions of their life skills. Combined fall and spring averages for each dimension was split by grade groups (middle school student, HS underclassmen, and HS upperclassmen) to examine possible differences between grade groups. High school upperclassmen averaged the highest on perceptions of their own life skills in seven out of eight dimensions, which included responsibility, problem solving, self-directedness, collaboration, communication, creativity, and work ethic. The only dimension that they did 
not have the highest average was time management. The middle school students had the highest average for time management and the high school underclassmen had the lowest in that dimension. High school underclassmen scored the lowest in three dimensions: responsibility, creativity, and work ethic. The high school underclassmen had the same average as the middle school students in problem solving, and collaboration. It is not surprising that high school upperclassmen have the highest averages in most of the dimensions. The average time that these high school upperclassmen have been at their prospective project-based learning schools is 3.06 years. The average time that high school underclassmen and middle school students have been the project-based learning schools is very similar. High school underclassmen averaged at the time of the survey was 1.74 years and middle school students averaged 1.33 years. The dimension that stood out was time management. Middle school students' average was the highest at 3.51, followed by high school upperclassmen at 3.4, and high school underclassmen at 3.23.

Because the ANOVA test showed responsibility between grade groups to be the most significant, it seems that the grade groups may have different perceptions of their own responsibility life skill. The fact that high school upperclassmen scored the highest on responsibility is not surprising due to the many projects and expectations they have to accomplish in order to graduate. Many of the high school upperclassmen have been at the project-based school for at least two or more years and understand the significance of completing projects, communicating with their advisors, being self-motivated and responsible for their work. They are also preparing for life after high school whether it is work or college.

Question 37 on the survey examined students perceptions on which life skills were needed most to help prepare for college. Communication, time management, and work ethic were ranked the highest (see Figure 2).

Another part of this research was asking students if they had any suggestions for ways that Avalon or MNCS could improve. Twenty two percent of students from Avalon were satisfied with no recommendations. Eleven percent of students suggested having better communication among students and teachers, allowing for more creativity, and helping students be more responsible. Five percent of students suggested increasing math education, providing more sports, providing more activities for newer students, helping students with time management, and providing more job skills classes. Interestingly, 0 out of $19 \mathrm{MNCS}$ students answered satisfied with no recommendations. Suggestions that they offered included: (1) $15.79 \%$ having more direction and assistance with projects; (2) $10.53 \%$ allowing for more creativity, increasing math education, having a more rigid structure; (3) $5.26 \%$ better communication among teachers and students, increased reading education, better technology, and more job skill classes. This information may be useful not only for these schools, but other project-based schools as they continue to evaluate their programs and curriculum.

\section{Limitations}

Several limitations of the study should be noted. First, possible bias related to the author's presence during the interviews and focus groups. All interviews and focus groups were recorded with the knowledge and approval from all interviewees. Questions were asked in a 
semi-structured format and the author was professional using a calm voice when asking questions. However, the author's presence during the interviews and focus groups may have fostered anxiety for some students that may or may not have hindered their responses. Second, the scope of the study was also limited to two project-based learning charter schools in rural and urban Minnesota. Third, the time frame of the study took place over a one-year period of time during the school year. In order to examine and compare students' life skill progress over a longer period of time, a suggestion would be to conduct a longitudinal study that follows students from the time they enter a project-based learning school until graduation. Finally, the author was unable to track individual student responses. This made it difficult to examine individual perceptions of students over a one-year time frame.

\section{Conclusions}

Data from this research clearly indicates that students are learning important life skills and perceive that they are improving various life skills while attending these schools. The curriculum and culture of both schools provides students with opportunities to develop their life skills through a semi-guided process, which allows students freedom in their choices of projects. Advisors are assigned to students to help keep them accountable and provide guidance as needed. Students are responsible for choosing their projects and completing each project through various modes of research, communication and collaboration with advisors, and at times with partners or groups. Ultimately, each student is responsible for the completion of his own work. Those life skills that are perceived by students to be most important include responsibility, self-directedness, collaboration, communication, creativity, and work ethic. Life skills that students perceived to have improved on the most while attending either MNCS or Avalon included but were not limited to communication, self-directedness/independence, and collaboration. There is a correlation between those life skills that students perceive as most important to life skills they perceive to have improved on. This correlation may be due to various factors which include: (1) expectations of the project-based learning schools for students; (2) expectations of the students on themselves; (3) types of projects students choose; (4) culture of teaching and learning; (5) social expectations such as family, community, and peers. Each of these factors could be researched more in-depth to better understand the possible correlations.

\section{References}

Bandura, A. (1977). Social learning theory. Englewood Cliffs, NJ: Prentice Hall.

Barron, B., \& Darling-Hammond, L. (2008). Teaching for meaningful learning: A review of research on inquiry-based and cooperative learning. Retrieved from http://www.edutopia.org/pdfs/edutopia-teaching-for-meaningful-learning.pdf

Bell, S. (2010). Project-based learning for the 21st century: Skills for the future. Clearing House, 83(2), 39-43. http://dx.doi.org/10.1080/00098650903505415

Boaler, J. (1999). Mathematics for the moment, or the millennium? Education Week, 17(29), 30-34. 
Brown, A. L., \& Campione, J. C. (1996). Psychological theory and the design of innovative learning environments: On procedures, principles, and systems. In L. Schauble \& R. Glaser (Eds.), Innovation in learning: New environments for education (pp. 289-335). Mahwah, NJ: Erlbaum.

Buck Institute for Education. (2007). Project-based learning handbook. Retrieved from http://www.bie.org.pbl/pblhandbook/intro

Creswell, J. W. (1998). Qualitative inquiry and research design. California: Sage Publication.

Geier, R., Blumenfeld, P. C., Marx R. W., Karjcik, J. S., Fishman, B., \& Soloway, E. (2008). Standardized test outcomes for students engaged in inquiry-based science curriculum in on text of urban reform. Journal of Research in Science Teaching, 45, 922-939. http://dx.doi.org/10.1002/tea.20248

Guzdial, M. (1997). Constructivism vs. constructionism. Retrieved from http://www.guzdial.cc.gatech.edu/commentary/construct.html

Harada, V., Kirio, C., \& Yamamoto, S. (2008). Collaborating for project-based learning in grades 9-12. Library Media Connection, 26(6), 14-16.

Hickey, D., Kindfeld, A., Horwitz, P., \& Christie, M. (1999). Advancing educational theory by enhancing practice in a technology-supported genetics learning environment. Journal of Education, 181, 25-55.

Katz, L. G., \& Chard, S. C. (1989). Engaging children's minds: The project approach. Norwood, NJ: Ablex Publishing Corporation.

Lynch, S., Kuipers, J., Pyke, C., \& Szesze, M. (2005). Examining the effects of highly rated science curriculum unit on diverse students: Results from a planning grant. Journal of Research in Science Teaching, 42(8), 912-946. http://dx.doi.org/10.1002/tea.20080

Newell, R. (2003). Passion for learning: How project-based learning meets the needs of $21^{\text {st }}$-century students. Lanham, MD: The Scarecrow Press.

Peverini, S. (2009). The value of teacher expertise and good judgment: Recent inspiring reading about assessment. Language Arts, 86(5), 398-402.

Popham, W. J. (2008). Transformative assessment. Alexandria, VA: Association for Supervision and Curriculum Development.

Ravitz, J. (2010). Beyond changing culture in small high schools: Reform models and changing instruction with project-based learning. Peabody Journal of Education, 85(3), 290-312. http://dx.doi.org/10.1080/0161956X.2010.491432

Savery, J. (2006). Overview of problem-based learning: Definitions and distinctions. Interdisciplinary Journal of Problem-Based Learning, 1(1), 9-20. Retrieved from http://docs.lib.purdue.edu/ijpbl/vol 1/iss1/3

Scardamalia, M., \& Bereiter, C. (1991). Higher levels of agency for children in knowledge 
building: A challenge for the design of new knowledge media. Journal of the Learning Sciences, 1, 37. http://dx.doi.org/10.1207/s15327809j1s0101_3

Secretary's Commission of Achieving Necessary Skills Report. (2001). Retrieved from http://wdr.doleta.gov/SCANS

Stager, G. S. (July, 2001). Constructionism as a high-tech intervention strategy for at risk learners. Paper presented at the National Education Computing Conference, Chicago, IL.

Strobel, J., \& van Barneveld, A. (2008). When is PBL more effective? A meta-synthesis of meta-analyses comparing PBL to conventional classrooms. Interdisciplinary Journal of Problem-Based Learning, 3, 44-58.

Swanson, J. L., \& Woitke, M. B. (1997). Theory into practice in career assessment for women: Assessment and interventions regarding perceived career barriers. Journal of Career Assessment, 5(4), 443-462. http://dx.doi.org/10.1177/106907279700500405

Tashlik, P. (2010). Changing the national conversation on assessment. Phi Delta Kappan, 91(6), 55-9. http://dx.doi.org/10.1177/003172171009100614

Toch, T. (2011). Beyond basic skills. Phi Delta Kappan, 92(6), 72-3. http://dx.doi.org/10.1177/003172171109200617

Trilling, B., \& Hood, P. (1999). Learning technology and educator reform in the knowledge age or "we're wired, webbed and windowed, now what?" Educational Technology, 39(3), $5-18$.

Walker, A., \& Leary, H. (2008). A problem based learning meta-analysis: Differences across problem types, implementation types, disciplines and assessment levels. Interdisciplinary Journal of Problem Based Learning, 3(1), 12-43.

Wurdinger, S., Haar, J., Hugg, R., \& Bezon, J. (2007). A qualitative study using project-based learning in a mainstream middle school. Improving Schools, 10(2), 150-161. http://dx.doi.org/10.1177/1365480207078048

Wurdinger, S., \& Qureshi, M. (2015). Enhancing college students' life skills through project based learning. Innovative Higher Education, 40(3), 279-286. http://dx.doi.org/10.1007/s10755-014-9314-3

\section{Glossary}

Charter schools: publicly funded schools in the United States which have been freed from some of the rules, regulations, and statutes that apply to other public schools in exchange for some type of accountability for producing certain results which are set forth in each charter school's charter (Wurdinger et al., 2007, p. 160).

Constructivism: a cognitive learning theory proposed by Jean Piaget, who argues that new knowledge is constructed by learners as they interact with new information (Guzdial, 1997; 
Stager, 2001).

Constructionism: a cognitive learning theory invented by Seymour Papert, professor of learning research at the Media Laboratory of Massachusetts Institute of Technology Constructionism which asserts that when students engage in building and manipulating objects or making projects by themselves, they are more likely to form new ideas and construct knowledge (Guzdial, 1997).

EdVisions: created in 1993 and comprised of teachers and other educational professionals who believe teachers should assume new professional roles and create opportunities for direct involvement in owning and operating various educational entities. The cooperative model allows entrepreneurial educators to create responsive, innovative, and efficient educational programs in their own communities. The mission of EdVisions is to create schools that build relevant learning using self-directed opportunities and empower students, parents, and teachers. (EdVisions, 2012).

Life skills: skills identified by the Secretary of Education's Commission on Achieving Necessary Skills Report (2001)as important life skills needed to be productive members of a work community.

Project-based learning: "a constructivist pedagogy intent on bringing about deep learning by allowing learners to use an inquiry based approach to engage in issues and questions that are real and relevant to their lives" (Wurdinger et al., 2007, p. 160).

Self-Efficacy: a person's beliefs or expectations about his or her ability (Bandura, 1977).

The No Child Left Behind Act (NCLB): aUnited States federal law enacted in 2001that reauthorizes a number of federal programs that aim to improve the performance of the United State's schools by increasing the standards of accountability for states, school districts, and schools, as well as providing parents more flexibility in choosing which schools their children will attend. NCLB also promotes an increased focus on reading and re-authorizes the Elementary and Secondary Act of 1965 (ESEA). NCLB is the most current federal legislation, which enacts the theories of standards-based education reform.

\section{Appendix}

Appendix 1. Semi-Structured Interview Questions for Students

1. What do you think life skills are?

2. What life skills do you think are important?

3. What types of life skills do you think your school helps you with?

4. Do you think this school has helped you improve your life skills?

5. Can you give specific examples of projects you have accomplished when you used life skills? 


\section{Macrothink}

6. What areas of life skills have you improved on the most?

7. Are there life skills that you would like to improve on and why?

8. Overall, do you see improvement in your life skills in the past year?

9. Do you feel that this school is helping you improve your life skills for the future? Why or why not?

10. Are there any areas of life skills that you would like to see more emphasis on and why?

Appendix 2. Focus Group Questions

1. What particular skills do you think are important to have for life? Why?

2. Do you think project-based learning helps you improve those life skills? If so, please explain.

3. Which of your life skills have improved since you have been at this school?

4. Which of your life skills do you feel need more improvement?

5. Are there certain aspects of project-based learning that have influenced your life skill development? If so, what aspects?

6. Do you feel project-based learning is helping to prepare you for life beyond high school? If so, why?

Appendix 3. Survey Questions for Students

\section{Please mark the answer that best describes you:}

1. How long have you been a student at this school?

$0-1$ year

2 years

3 years

4 years

$5+$ years

2. What grade level are you currently?

$6^{\text {th }}$ grade

$7^{\text {th }}$ grade

$8^{\text {th }}$ grade

$9^{\text {th }}$ grade

$10^{\text {th }}$ grade 
$11^{\text {th }}$ grade

$12^{\text {th }}$ grade

\section{Please rank the following:}

\begin{tabular}{|l|l|l|l|l|}
\hline 1 & 2 & 3 & 4 & 5 \\
\hline Poor & Fair & Satisfactory & Good & Excellent \\
\hline
\end{tabular}

3. How do you rank yourself at completing projects on time?

$\begin{array}{lllll}1 & 2 & 3 & 4 & 5\end{array}$

4. How do you rank yourself as a problem solver?

$\begin{array}{lllll}1 & 2 & 3 & 4 & 5\end{array}$

5. How do you rank yourself at setting goals?

$\begin{array}{lllll}1 & 2 & 3 & 4 & 5\end{array}$

6. How do you rank yourself at finding new solutions to problems?

$\begin{array}{lllll}1 & 2 & 3 & 4 & 5\end{array}$

7. How well do you share your ideas with others?

$\begin{array}{lllll}1 & 2 & 3 & 4 & 5\end{array}$

8. How well do you work with others?

$\begin{array}{lllll}1 & 2 & 3 & 4 & 5\end{array}$

9. How do you rank yourself at following through with commitments?

$\begin{array}{lllll}1 & 2 & 3 & 4 & 5\end{array}$

10. How well do you work as a team member?

$\begin{array}{lllll}1 & 2 & 3 & 4 & 5\end{array}$

11. How much do you challenge yourself to try new things or approach areas where you might be weak/less knowledgeable?

$\begin{array}{lllll}1 & 2 & 3 & 4 & 5\end{array}$

12. How well do you listen to others?

$\begin{array}{lllll}1 & 2 & 3 & 4 & 5\end{array}$

13. How do you rank yourself as a person others can count on?

$\begin{array}{lllll}1 & 2 & 3 & 4 & 5\end{array}$ 
14. At what level do you rank your creativity?

$$
\begin{array}{lllll}
1 & 2 & 3 & 4 & 5
\end{array}
$$

15. How well do you help others make decisions?

$$
\begin{array}{lllll}
1 & 2 & 3 & 4 & 5
\end{array}
$$

16. How well do you complete things you have started?

$$
\begin{array}{lllll}
1 & 2 & 3 & 4 & 5
\end{array}
$$

17. How well do you look at various options before making decisions?

$$
\begin{array}{lllll}
1 & 2 & 3 & 4 & 5
\end{array}
$$

18. How do you rank yourself as motivated to complete your goals?

$$
\begin{array}{lllll}
1 & 2 & 3 & 4 & 5
\end{array}
$$

19. How well do you find different or original ideas in your work?

$$
\begin{array}{lllll}
1 & 2 & 3 & 4 & 5
\end{array}
$$

20. How well do you communicate with others?

$$
\begin{array}{lllll}
1 & 2 & 3 & 4 & 5
\end{array}
$$

21. How well do you finish things without help from others?

$$
\begin{array}{lllll}
1 & 2 & 3 & 4 & 5
\end{array}
$$

22. How dependable are you?

$$
\begin{array}{lllll}
1 & 2 & 3 & 4 & 5
\end{array}
$$

23. How do you rank yourself at making good choices?

$$
\begin{array}{lllll}
1 & 2 & 3 & 4 & 5
\end{array}
$$

24. How well do you listen to others?

$$
\begin{array}{lllll}
1 & 2 & 3 & 4 & 5
\end{array}
$$

25. How well do you make plans for yourself?

$$
\begin{array}{lllll}
1 & 2 & 3 & 4 & 5
\end{array}
$$

26. How do you rank yourself as a creative thinker?

$$
\begin{array}{lllll}
1 & 2 & 3 & 4 & 5
\end{array}
$$

27. How do you rank yourself as a person others can come and talk to?

$\begin{array}{lllll}1 & 2 & 3 & 4 & 5\end{array}$ 
28. How well do you take responsibility for your actions?

$$
\begin{array}{lllll}
1 & 2 & 3 & 4 & 5
\end{array}
$$

29. How do you rank your work ethic?

$$
\begin{array}{lllll}
1 & 2 & 3 & 4 & 5
\end{array}
$$

30. How good are you at making adjustments to your projects while working to complete them?

$$
\begin{array}{lllll}
1 & 2 & 3 & 4 & 5
\end{array}
$$

31. How do you rank yourself at working hard to achieve your goals?

$$
\begin{array}{lllll}
1 & 2 & 3 & 4 & 5
\end{array}
$$

32. How well do you finish things on time?

$$
\begin{array}{lllll}
1 & 2 & 3 & 4 & 5
\end{array}
$$

33. How well can you figure out how things should work?

$$
\begin{array}{lllll}
1 & 2 & 3 & 4 & 5
\end{array}
$$

34. How do you rank your communication skills?

$$
\begin{array}{lllll}
1 & 2 & 3 & 4 & 5
\end{array}
$$

35. How well do you continue working even when circumstances are difficult?

$$
\begin{array}{lllll}
1 & 2 & 3 & 4 & 5
\end{array}
$$

36. How well have your life skills improved to this point in time?

$$
\begin{array}{lllll}
1 & 2 & 3 & 4 & 5
\end{array}
$$

Explain:

37. What life skills do you think are important to best prepare you for after graduation?

\section{Question Key:}

$>$ Time Management: $3,16,21,32$

$>$ Responsibility: 9, 13, 22, 28

$>$ Problem Solving: 4, 6, 17, 23, 33

$>$ Self-Directedness: 5, 18, 25, 30

$>$ Collaboration: $7,8,10,15$

$>$ Communication: 12, 20, 24, 27, 34

$>$ Creativity: $14,19,26$ 
Work Ethic: 11, 29, 31, 35

$>$ Overall Improvement: 36

Scale Used: 1 = Poor; 2 = Fair; 3 = Satisfactory; 4 = Good; $5=$ Excellent

\section{Privacy Statement}

The names and E-mail addresses entered in this journal's site will be used exclusively for the purposes of this journal and will not be made available for any other purpose or to any other party.

\section{Copyright Disclaimer}

Copyright for this article is retained by the author(s), with first publication rights granted to the journal.

This is an open-access article distributed under the terms and conditions of the Creative Commons Attribution license (http://creativecommons.org/licenses/by/3.0/). 